IN3 Working Paper Series

INTERNET INTERDISCIPLINARY INSTITUTE

ISSN 2013-8644

\title{
Party Activism in the Internet Era Testing for Reinforcement and Mobilization
}

Ana S. Cardenal Izquierdo (acardenal@uoc.edu)

Universitat Oberta de Cataluya

Working Paper

Working Paper Series WP10-001

Submitted in: 2010

Accepted in: 2010

Published in: 2011

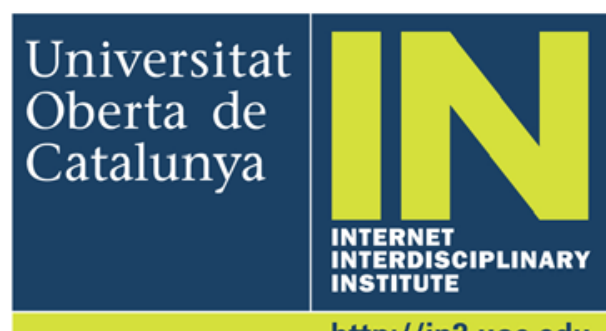




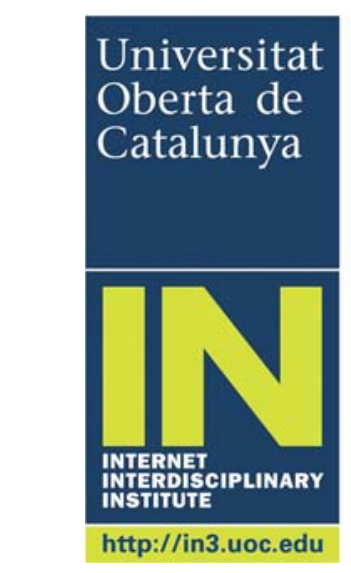

Internet Interdisciplinary Institute (IN3)

http://www.in3.uoc.edu

Edifici MediaTIC

c/ Roc Boronat, 117

08018 Barcelona

Espanya

Tel. 934505200

Universitat Oberta de Catalunya (UOC)

http://www.uoc.edu/

Av. Tibidabo, 39-43

08035 Barcelona

Espanya

Tel. 932532300

\section{(C)}

The texts published in this publication are - unless indicated otherwise - covered by the Creative Commons Spain Attribution-Non commercial-No derivative works 3.0 licence. You may copy, distribute, transmit and broadcast provided that you attribute it (authorship, publication name, publisher) in the manner specified by the author(s) or licensor(s).

The full text of the licence can be consulted here:

http://creativecommons.org/licenses/by-nc-nd/3.0/es/deed.en. 


\section{Table of contents}

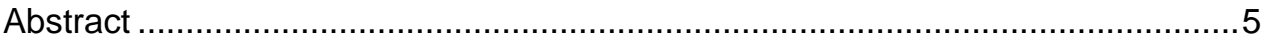

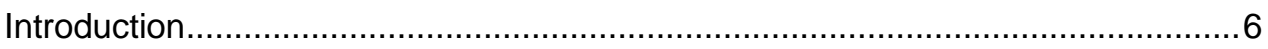

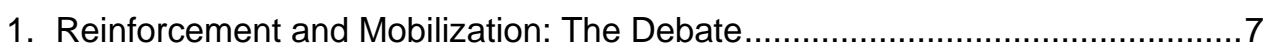

2. A General Model of Participation ...................................................... 9

3. How Internet changes the logic of party member participation....................... 12

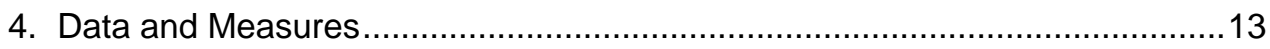

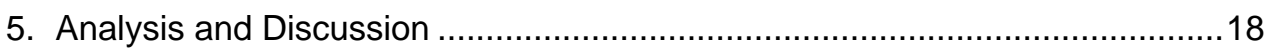

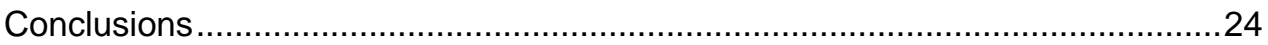

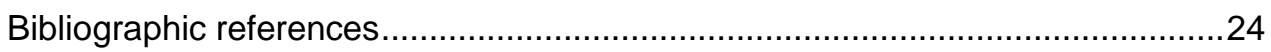




\section{Party Activism in the Internet Era \\ Testing for Reinforcement and Mobilization}

Ana S. Cardenal (acardenal@uoc.edu)

Universitat Oberta de Catalunya

\section{Recommended citation:}

CARDENAL, Ana S. (2011). "Party Activism in the Internet Era: Testing for Reinforcement and Mobilization" [online working paper]. (Working Paper Series; WP10001). IN3 Working Paper Series. IN3 (UOC). [Accessed: dd/mm/yy]. <http://in3wps.uoc.edu/ojs/index.php/in3-working-paper-series/article/view/n10cardenal/n10-cardenal> 


\begin{abstract}
This paper takes the debate about the reinforcement and mobilization effects of the Internet to an area that has yet to be explored under this framework: party activism. It asks whether the Internet is modifying existing patterns of member participation and mobilization - i.e., of activism -- within parties. To explore this question and test for reinforcement and mobilization in party activism it uses an online survey to party activists of four Catalan parties (PSC, CDC, ERC, IC-V) that together represent more than $80 \%$ of the vote in national and regional elections. The analysis finds some support for the mobilization hypothesis. In contrast to traditional forms of party activism, Internet tends to mobilize party members who are frequent Internet users, who have approached the party through the net, who live in large municipalities and who have strong preferences in the issue of national identity.
\end{abstract}

\title{
Keywords
}

Political Parties, Party Activists, Activism, Internet, Cyber-Activism. 


\section{Introduction}

Is the Internet becoming a new arena for political mobilization? Is the Internet mobilizing people who have traditionally been inactive? Is the Internet making a difference in who is participating politically, or, on the contrary, it is making no difference in who is being mobilized politically? These questions are at the heart of a now long standing debate examining the effects of the Internet in political participation. This debate has produced two well-known positions: those who contend that the Internet is not mobilizing new people into the political arena but only reinforcing existing patterns of participation and those who argue that that the Internet is bringing into the political process people with a different profile to the traditional one.

This paper examines this question in an area that has yet to be explored under this framework: party activism. To test for reinforcement and mobilization in party activism this paper compares patterns of activism offline and online in Catalonia. I use data of an online survey conducted from March to June of 2009 to party activists of four Catalan political parties: the Catalan Socialist Party (PSC), the Catalan Nationalist Party (CDC), the Catalan Left-Wing Republican Party (ERC), and the Catalan RedGreen Coalition, IC-V. Together these four parties represent more than 80 percent of the vote in both national and regional elections and they enroll more than 85 percent of all party members in Catalonia. Therefore, the analysis should give us a quite accurate description of actual changes in party activism in Catalonia in the Internet era.

The structure of the article is as follows. In the next section I present the debate on reinforcement and mobilization. In the third section, I sketch a general model of participation. In the fourth section, I discuss how Internet may affect the logics of participation by affecting the resources needed for online participation, the calculus of participation and the context and organizational resources most suited for online mobilization. In the fifth section, I present the data and measures. In the sixth section, I proceed with the analysis and discuss the results. In a final section, I conclude. 


\section{Reinforcement and Mobilization: The Debate}

The debate examining the effects of the Internet in political participation has produced two well known positions. On the one hand, there are those who contend that the Internet intensifies participation of those already active in politics. The argument of scholars taking this side is as follows: since participating in politics and accessing and using Internet are related to the same kind of resources (mainly education, but in general the variables related to the socio-economic status), Internet is not likely to mobilize new people into the political process, and we are likely to observe a reinforcement of existing patterns of participation (Hill and Hughes, 1998; Norris, 2000; Margolis and Resnik, 2000). On the other hand, there are those who contend that the Internet is mobilizing people who were previously inactive (Krueger, 2002; Tolbert and McNeal, 2003; Gibson, Lusoli, and Ward, 2005; Anduiza, Gallgo and Cantijoch, 2009; Cantijoch, 2009; Borge and Cardenal, 2011). For example, Krueger (2002) contends that online participation does not requires the traditional resources associated to political participation, but new resources, such as Internet skills, which may increase the mobilization potential of the Internet (Krueger, 2002; Anduiza, Gallego and Cantijoch, 2009). Others argue that the Internet may have an effect on mobilization by facilitating involuntary exposure to political information (Cantijoch 2009); still others argue that it may affect mobilization by increasing both voluntary and involuntary exposure to e-stimuli and requests for participation (Gibson, Lusoli and Ward, 2005; Borge and Cardenal, 2011).

The question on whether the Internet tends to reinforce existing patterns of participation and political contestation or has the potential to change these patterns by giving opportunities to the less advantaged, has not only taken place at the individual level, but also at the aggregate level - at the level of the political organizations. At this level, the central question has been whether Internet is helping to level the playing field by providing small organizations with a new arena to compete in more equal terms with large organizations. In this area, some scholars have contended that electoral competition online is only replicating the existing power-balance in the offline world leading to the so-called "normalization hypothesis" (Margolis \& Resnick, 2000). Others, in contrast, contend that, since Internet gives a comparative advantage to small organizations, it is helping to level the playing field in elections. This has been known as the "equalization hypothesis". ${ }^{1}$

Underlying these debates there is a similar concern with the question of how the Internet may shift or affect the existing power-balance in different areas. For example,

\footnotetext{
${ }^{1}$ There are numerous empirical studies examining this question which yield contradictory results. For a meta-analysis of the effects of the Internet in the electoral arena, see Strandberg, 2008
} 
underlying the first debate about the effects of the Internet on political participation is the question of whether Internet may alter existing patterns of inequality in political participation by giving voice to those that have been traditionally excluded from the political process (Krueger, 2002). Also, underlying the debate on the effects of the Internet in electoral competition is the question of whether Internet will help to level up the playing field in electoral politics by giving an advantage to small organizations over big ones. In other words, underlying current debates about the effects of Internet in politics is the question of whether Internet is shifting the existing power structure at the level of both individuals and organizations and by so doing is helping to shape political conflict in different ways.

This paper takes this debate and the concerns underlying it to an area that has yet to be explored under this framework: party activism. Although there are some studies that have looked at the effects of the Internet on party activism, they have done so from a different perspective, and with different questions and goals in mind. The main goal of these studies has been to explore how Internet is affecting the quality of relations between party leaders and members; and more specifically, whether it is widening and deepening participation within political parties (Lusoli and Ward, 2004; Ward, Lusoli and Gibson, 2002; Löfgren, 2000; 2003).

This paper is also concerned with participation, but it is not concerned with participation oriented towards internal party affairs ("inward-oriented" participation), but with participation oriented towards helping to achieve the goals of the party as an organization ("outward-oriented" participation). In other words, this paper asks not about the effects of the Internet in internal party relations, but about the effects of the Internet in the kind of participation directed towards achieving party goals. Is Internet making a difference in who is participating as well as in how much he or she is contributing in order to help achieve the goals of parties? Is Internet changing existing patterns of activism and party mobilization? In particular, this paper wants to know whether Internet is increasing or changing the patterns of party members' activism or is simply reinforcing existing levels and patterns of party activism.

In line with the existing literature, the reinforcement hypothesis in this paper states that Internet does not have an effect in existing patterns of activism but only replicates them (the null hypothesis). This hypothesis predicts that those who are mobilizing online are those that are already active offline and at the aggregate level we observe patterns of activism online conforming to patterns of activism offline. In this scenario, Internet does not widen participation by mobilizing members who were previously inactive, but it extracts more from the already committed. In this scenario, Internet may increase aggregate levels of activism through the intensification of activism, but it does not affect either existing patterns of activism or the distribution of activism across parties.

In contrast, the mobilization hypothesis states that Internet does have an effect in existing patterns of activism by mobilizing new members online (the alternative hypothesis). This hypothesis does not preclude certain levels of reinforcement, where 
members who are active offline are also active online, but it differs from the previous hypothesis in that it expects members who were previously inactive to become active online and that to have effects that are observable at the aggregate level. In this scenario, the mobilization of new members' online causes patterns of activism online to differ from patterns of activism offline.

Note that testing these hypotheses for party activism has consequences for the debate in the fields of both political participation and electoral competition. To the extent that party activists provide inputs into policies and candidates through their parties they are participants in the political process and have an influence in political outcomes. If we find that Internet mobilizes new members, with a different profile and characteristics, this may shift the power-balance within the party and have an impact in the actual policies of parties. But note also that party activists are a resource of parties as organizations; among other things, they provide them with free labor. In that sense a mobilization effect can shift resources from one party to another and alter the balance of power in the electoral arena.

\section{A General Model of Participation}

Before sketching any model of participation, I first have to spell out what it is that I am trying to explain by participation or by the decision to participate. The decision to participate in this paper refers to the decision of contributing with some of amount of resources, such as money, energy and time, to helping to achieve the goals of the party of which one is a member or a sympathizer. In this paper, since 88 percent of the sample is made up of party members, the decision to participate does not refer to the decision of whether to join or not a party as an activist (Aldrich, 1983a), but to the decision of how much to contribute in valuable resources (time, energy and money) to help your party achieve its goals. As a result, the dependent variable in this paper participation - is measured as continuous, and is closely related to the dependent variable used by Whitley and Seyd (1998) in their study of party activism, where they wanted to explain the amount of resources that party members actually invest in trying to help the party achieve its goals.

Existing models of party activism are in general poor. Several models have been developed to account for party activism. Whiteley and Seyd (2002) and Granik (2005) distinguish at least four: the "social psychological", the "civic voluntarism", the "rational choice" and the "general incentive" models. Whitely and Seyd (1998) themselves use the general incentive model to explain the levels of activism of members of the British parties. The general incentive model starts from the rational choice model but adds new variables and measures of group influence and expressive incentives (Granik,

9 
2005: 598). All these models can be critized for their lack of parsimony. ${ }^{2}$ The main strength of the general incentive model is that it departs from the rational choice model; its main weakness is that it tries to improve the rational choice model by adding too many variables, loosing what is the main advantage of the rational choice approach: its parsimony.

To sketch a general model of participation I turn to the rational choice approach. In particular, I follow Aldrich (1983a, 1983b) who uses the original voting model, as formulated by Riker and Ordershook (1973), as the baseline model to account for the decision to join or not a party - i.e, to become an activist. ${ }^{3}$ Aldrich (1983a, 1983b), though, adapts some of the terms of the original voting model to his variable of interest -i.e, the decision of whether to become or not an activist. Among other assumptions, Aldrich assumes that the costs of participating (the " $\mathrm{C}$ " term in the original model) will never be higher than the expressive benefits of voting (the "D" term). He also assumes that the decision to join a party will always be perceived as helping to increase its chances of achieving its goals (the "P" term in the orginal model will always be positive and constant for all potential activists). Thus, what ultimately explains a positive reward from the decision to join a party is the B term. That is, the utility that an individual derives from having his or her party win and implementing the individual's ideal policies. This utility, in turn, is a function of the distance, as perceived by the individual, between the policies advocated by his or her party and the policies advocated by the own party's main adversary. In other words, the decision to join or not a party depends mainly on two distances: the distance between the inidvidual and the party that is closer to his or her ideal policies, and the distance between the party that is closer to the individual's ideal policies and its main competitor.

The simplicity of Aldrich argument allows him to test different hypothesis when certain conditions change. His argument is not only convenient (by virtue of being simple), but is also plausible and realistic because he only attempts to account for the decision to participate of rank-and-file activists and not of activists with public or party

\footnotetext{
${ }^{2}$ Granik (2005) is also critical with the general incentive model but unfortunately not always for the good reasons. Her contribution is basically to propose and develop better measures of the variables included in the general incentive model but by focusing her attention on developing better measures of the variables in the model she looses sight of the one really important problem in these models: the excess of independent variables. The problem with these models is that they lack parsimony. They include so many variables that they lack explanatory power.

${ }^{3}$ To remind the reader, the model accounting for the decision to vote as formulated originally by Riker and Ordershook contained the following variables:

$R=P B+D-C$

Where,

$\mathrm{R}=$ the reward of deciding to vote,

$\mathrm{P}=$ the probability that your vote will determine the outcome by breaking a tie between the main adversaries,

$\mathrm{B}=$ the benefit obtained from having your candidate elected as compared to having the other candidate elected,

$D=$ the benefit obtained from the act itself of participating.

$\mathrm{C}=$ the costs of participating.
} 
offices or career aspirations (Aldrich, p. 976). My sample includes both grass-roots and elite activists; hence, together with the value of policy, I will consider the role of selective incentives in the decision to participate in contrast to Aldrich (1983a) who decides to keep them out of the model. ${ }^{4}$

In this paper, selective incentives stand for private benefits. This leaves out, as selective incentives, the incentives associated to the benefits of the collective goals. ${ }^{5}$ Only material benefits, such as offices and a professional political career, and process or expressive benefits, such as those derived from the act of participating, are included in the model as selective incentives.

Both the benefits of policy and selective incentives are variables intervening in the individual calculus of participating. Both these are variables are located at the individual level and affect the decision to participate. Yet not only variables at the individual level affect the calculus of participating: there are also system level variables affecting the decision to participate.

Since Olson (1965) we know that size is an important variable influencing participation, the decision to join and belong in a group. Size not only affects transaction costs (information, communication and coordination) involved in group formation, but also, and more importantly, it affects the individual calculus of participating. When a group is small not only the contribution of a single individual in helping to achieve the collective good is more important, but also the expected benefits from the collective good are greater. In other words, size affects two important terms of the previous equation, the "p" and the "b" terms.

More recently, some works have tested the effect of size on party members' participation (Tan, 1998; Weldon, 2006). Weldon (2006) concludes that size has clearly a positive effect on participation; that is, the smaller the party the more members' participate. Tan (1998) concludes that while size has a positive direct effect on participation, it has a negative indirect effect on participation. This is so because he founds, in contrast to his initial expectations, that the complexity and territorial presence of a party organization has a positive effect in participation (p. 196)

This discussion takes us to the last two variables whose effect on party members' participation this study will explore: party size and the type of organization.

\footnotetext{
${ }^{4}$ Aldrich also recognizes the role of selective incentives, but contends that they depend on the party. Since he is not interested in exploring the role that the party-as-organization has in the decision to participate he decides to keep them constant.

${ }^{5}$ Clark and Wright (1961) distinguish three different kinds of selective incentives. The general incentives model builds upon these different kinds of incentives. The three kinds of selective incentives that following Clark and Wright are used in the literature on party activism are: purposive (policy goals); material (offices and career) and solidary (process-oriented).
} 


\section{How Internet changes the logic of party member participation}

Much has been said about how the Internet may facilitate a more participatory environment within the party; about how it could foster participation by party members in party decisions (Lusoli and Ward, 2004; Ward, Lusoli and Gibson, 2002; Löfgren, 2000; 2003). However, almost nothing has been said about how the Internet may shift the logic of party member participation when it comes to outward participation; that is, how it may affect incentives to participate in order to help parties attain their goals. Internet reduces the costs of participation. It is clearly not the same, in terms of the amount of time and energy invested, to attend a local party meeting or to go and meet a party leader at his office than to follow a local debate or discussion online and to contact a party leader online. This cost-reducing effect of the Internet could reduce the role of "selective incentives" in participation. Olson (1965) argued that the benefits of a collective good alone, without the aid of selective incentives, could not account for the formation and maintenance of large organizations. Voluntary organizations need to rely on selective incentives, in the form of private goods, in order to secure the voluntary work of supporters and followers. One of these incentives in European parties has been formal membership. Formal membership works both as an expressive and as a material selective incentive because it strengthens feelings of belonging to the group and gives members rights over important decisions of the party. When the costs of participation are high, as in offline activism, the marginal utility of being a formal member is probably high, because feelings of belonging and having the right to decide in the affairs of the organization can partially compensate for high participation costs. But in a situation were the costs of participation dramatically decrease, as in online activism, formal membership may loose much of its utility as a compensation mechanism since it becomes so easy to help to promote your party's goals online. Hence, we would expect membership to make more of a difference in offline participation than in online participation. And we would also expect members to contribute more to offline participation relative to online participation and sympathizers to contribute more to online participation relative to offline participation.

But while the Internet reduces the costs of participating, to take advantage of the time and energy savings that it facilitates, specific resources are needed: individuals need to be familiar with the new media and have enough Internet skills to be able to use it efficiently. In other words, online participation may not require the same kind of resources that were so important for participation offline, but it requires skills that are specific to the new media. Hence, we would expect frequent and skilful Internet users to be more likely to be active in online participation while we would expect this factor to have no effect in offline participation. 
Third, and most interestingly, followers may perceive the new media as potentially a new arena in which to shape political conflict. In fact, not only have we been exposed to arguments about the Internet's capacity for levelling the playing field in electoral competition, but also we have seen numerous examples of this. For example, in the last US presidential primaries, Obama managed to outplace Hillary Clinton as the favourite candidate partly by building a strong grass-roots movement through the Internet. This and many other examples may encourage followers to use the Internet in order to re-shape political conflict. In particular, Internet may be perceived by followers as an arena that may help to shift the existing power balance by enhancing the visibility of emerging issues that may have been silenced in the mainstream media. In this sense, we would expect activists with strong preferences in issues that have either been silenced in the traditional media or have been the goals of a minority to have a higher proclivity to participate online than offline. This includes Catalan national identity issues, which might have gained visibility in the local press and media of Catalonia but which continue to be silenced in the national media.

Finally, not only factors at the individual level may affect incentives to participate online; factors at the contextual level may also help explain online mobilization. Certain characteristics of organizations may give them an advantage in the online environment (Ward, Gibson and Lusoli, 2003). Decentralized organizations with loose ties and nonhierarchical structures - such as protest or advocate organizations -- have been proved to be more efficient at mobilizing people online than centralized and more hierarchical organizations. Although parties tend to fit into the pattern of formal and hierarchical organizations there is some variation in organizational characteristics among the parties included in this study. Hence, if contextual factors in general and organizational characteristics in particular do make a difference in the ability to mobilize support online, we should observe parties to have a positive effect in online mobilization.

\section{Data and Measures}

To test for the reinforcement and mobilization hypotheses, this paper uses an online survey to party activists of four Catalan political parties that together account for more than $80 \%$ of the vote. These four parties are: the Catalan Socialist Party, PSC; the Catalan Nationalist Party, CDC; the Catalan left-wing pro-independence party, ERC; and the Catalan left-wing party made-up of a coalition of ex-communists and greens, IC-V. The survey was sent by each party to a random list of party activists that included members, sympathizers and web-visitors. In all cases, except for ERC, the list included party activists of all ages. Unfortunately, ERC did not send the questionnaire 
to activists of ages below 26 years. While this is an obvious limitation to reach conclusions about online mobilization within this party, we decided to use ERC's truncated sample because it may still add important information to a study about activists' offline and online mobilization.

The rate of response in each party was $2.6 \%$ for the PSC, 3.4\% for CDC, $16 \%$ for $\mathrm{ERC}$ and $5 \%$ for IC-V. All these rates of response are bellow the rate of response showed by members of the British parties - around 20\% (Lusoli and Ward, 2004; Whiteley and Seyd, 2004), but then compared with European standards, Spain has a tradition of low political participation that has also reflected in lower percentages of party enrollment. The differences across parties can be partly explained by size, since the largest parties, the PSC and CDC, have the lowest rate of response and the smaller ones, IC-V and ERC, have the highest ones. Size, however, does not seem to explain the high rate of response showed by ERC. First, ERC is not a small but medium size party. Second, rates of response in ERC are three to five times higher than the rest of the parties. There are two possible explanations for the high rates of response in ERC. The first is that the mailing list of ERC could have been much more targeted than that of any other party. The second has to do with the peculiar structure of ERC. Since in ERC party members participate in all the important decisions affecting the party, ERC has developed a strong participatory tradition.

In total, this study counts with a sample of 1357 party activists that responded and finished the questionnaire, of which $39.72 \%$ (539) belong to the PSC, $25.13 \%$ (341) to CDC; $23.88 \%$ (324) to ERC; and $11.27 \%$ (153) to IC-V. Although the study aimed to target both members and nonmembers, an overwhelming majority of respondents are party members (89.31\%); 8 percent of respondents are party sympathizers, and only a tiny 2 percent are web-visitors. The sample is also made up mainly of men: one out of four respondents are men $(75.26 \%)$ while only one out four are females $(24.74 \%)$. As expected (since this is an online survey), most respondents are frequent Internet users: 72.07 percent of respondents report using the Internet 6-7 days per week; 16.20 percent, report using it 3-5 days per week; and 7 percent report using it 1-2 days per week. Only a tiny few of the respondents (5\%) report using the Internet few times a month or less frequently than that. Finally, almost 40 percent of the sample $(38.84 \%)$ report holding an office, either within the party or a public office. Table 1 bellow summarizes this information showing these figures disaggregated by party.

Table 1. Sample descriptive figures

\begin{tabular}{llllll} 
& $\begin{array}{l}\text { Rate of } \\
\text { response }\end{array}$ & Frequencies & Women & $\begin{array}{l}\text { Activists } \\
\text { holding } \\
\text { an office }\end{array}$ & Members \\
\hline PSC & $2,6 \%$ & 539 & 146 & 166 & 425 \\
$\%$ & & 39,72 & 27,29 & 30,08 & 78,85 \\
\hline CDC & $3,4 \%$ & 341 & 84 & 157 & 333
\end{tabular}




\begin{tabular}{llllll}
$\%$ & & 25,13 & 24,93 & 46,04 & 97,65 \\
\hline ERC & $16 \%$ & 324 & 59 & 135 & 320 \\
$\%$ & & 23,88 & 18,32 & 41,67 & 98,77 \\
\hline ICV & $5 \%$ & 153 & 44 & 69 & 134 \\
$\%$ & & 11,27 & 28,95 & 45,1 & 87,58 \\
\hline TOTAL & & 1,357 & 333 & 527 & 1.212 \\
$\%$ & & 100,00 & 24,74 & 38,84 & 89,31 \\
\hline
\end{tabular}

To test whether patterns of activism online conform to patterns of activism offline, this paper has constructed two measures of participation, one of participation offline and one of participation online. Both these measures are based on additive indexes. Offline activism includes activities such as to work as a voluntary doing administrative work for the party; attend local meetings; attend central and sectoral meetings; talk with friends about politics and the party; attend party events and demonstrations; campaign for the party; donate money. Online activism includes activities such as registering on calendar events, downloading campaign material, entering on the YouTube or flick of the candidate or party, circulating a candidate or party video, contacting a party leader or candidate through email, circulating political information in social networks, participating in discussions in forums (a complete list of the offline and online activities is included in the appendix). Since the number of items for each type of activism varies greatly, the additive indexes have been normalized to an index between 0 and $1-$ i.e., have been transformed into proportions. This transformation is convenient because it allows comparing the distributions by using the same scale and later in the analysis comparing the coefficients across the two models of activism.

As for the independent variables, I use the same basic set of variables to account for both online and offline participation. I include both individual and contextual variables affecting the individual calculus of participation. At the individual level, I use the value of policy and different kinds of selective incentives as the most important variables affecting the decision of how much to contribute to your party. At the system level, I use the individual parties as an indirect measure of "size" and "type" of an organization. In addition, I introduce specific variables that have been used to explain online participation. I now specify some of the measures used for these variables.

To measure the value of policy or the B term I use the standard measure in the literature on political competition and spatial modeling: the distance perceived by the activist between his or her own party and his or her own party's main competitor. The assumption here is that the greater the perceived distance between one's own party and its competitor, the greater the utility for the activist of having his/her party win the government and implement his/her preferred policies. I use distance to measure the value of policy in the two relevant dimensions of conflict in Catalonia: the ideological or traditional left-right divide and the territorial or national identity dimension. In addition to this measure I use an index of Catalan nationalism. The reason for using this index, in 
addition to distance, is to test whether having stronger Catalan identity feelings increases the propensity of activists to participate. Note that in contrast to distance this measure takes into account the position of the activist in a scale that moves from Spanish nationalism (0) to Catalan Nationalism (10) and assumes that being located or moving towards one extreme of the scale - Catalan nationalism - not both increases the propensity to participate. But why should we expect Catalan identity feelings and not Spanish identity feelings to increase the propensity of activists to participate? We expect them to value policies in this dimension more simply because they identify with the level of government at which these policies are made. Hence, I use self-placement in an index of Catalan nationalism as an alternative measure of the value of policy in the territorial or national identity dimension.

To capture the influence of selective incentives in participation, I use three different indicators. The first measure is dichotomous and distinguishes between members holding an office (coded with a 1 ) and not holding one (coded with a 0 ). I assume that those members holding a public or party office have an additional incentive to participate since they derive private benefits from their party's success. The second is an ordinal variable that measures proximity to the party. We assume that some of the expressive benefits associated with the act of participating (the "D" term in Riker's original model) can be captured by the proximity to the party. The greater the proximity to the party, for example if one is a formal member, the greater the feeling of belonging to the group and the greater the expressive benefits of the act itself of participating. Aside from affecting expressive or solidary benefits, being a member also carries some private benefits ("rights") that not being a member do not carry. Thus, we should expect formal members to have an additional incentive to participate than non members. Finally, we use years of membership also as a proxy for expressive or solidarity incentives. Here the assumption is that the longer you have been in a party the greater the attachment and the greater the benefits you obtain from the act of participating in its behalf.

As another cluster of variables, I use the parties to test for the influence of systemic variables in participation. I can do this because there is enough variation across parties regarding size and type of organization. I do not substitute the cases for variables, as Przeworski and Teune (1968) advice to do, because I do not have enough observations at the aggregate level to test for the influence of these systemic variables in participation. Including the individual parties in model, however, can help to suggest explanations about the influence of these kinds of variables in participation.

In addition to these variables, which can be seen as the "core" variables of the general model of participation, I introduce also specific variables that have been used to explain online participation. First, it has been argued that what matters for online participation are certain specific skills akin to the new media, such as Internet familiarity and expertise (Krueger, 2002; 2006; Best and Krueger (2005). To test for the influence of Internet skills in online participation I use the frequency of use of the Internet. Since almost 90 percent of respondents use the Internet on a weekly basis I 
use a very restrictive measure of frequency: only those activists that use the Internet 67 days per weeks are considered frequent Internet users. Second, some authors have found that the size of the municipality is a strong predictor of the participation experiences at the local level (Borge et al., 2009) Third, it has also been argued that that members that approach and join the party online tend to be most active online (Lusoli and Ward, 2004; Ward, Lusoli and Gibson, 2002). That is, that the way of approaching the party is relevant for predicting online participation. If all these variables prove to be relevant to explain participation online and not participation offline we should have some support for the mobilization hypothesis.

As controls, I include some socio-demographic variables, such as age, gender, and education. Age is a continuous variable with mean of 47,10 years and maximum and minimum values of 17 and 94 years, respectively; gender is a dichotomous variable coded as 1 for female and 0 for male; education is an ordinal variable made up of 5 categories going from primary studies to high university studies. Except for age and possibly gender for online participation, I do not expect any of these variables to have an influence in either type of participation. Education has proved to be a powerful predictor of participation. However, here we are dealing with a subset of the population that already participates in politics; hence, to the extent that there is not enough variation in the dependent variable we do not expect education to have a positive and significant effect on traditional participation. As for online participation, Krueger (2002, 2006) has found that education has no effect. Thus, we neither expect education to have an effect on online participation.

As for the models, since the dependent variable is continuous (an additive index of participation that has been normalized to an index from 0 to 1 ), I use linear regression to estimate the effect of the independent variables in party members' participation. Having specified the measures and the models, I need to specify what would be a confirmation of our two alternative hypotheses. If we find that the same set of variables that explain offline activism also explain online activism this data will support the reinforcement hypothesis. If, on the contrary, we find that the set of variables that explain offline activism do not explain online activism and that there is a specific set of variables that accounts for activism online but not for offline activism we will have some support for the mobilization hypothesis. Regardless of our findings, I assume that there is always some degree of overlapping between the two types of activism and hence that there is always some degree of reinforcement. To measure this overlapping effect I use "offline activism" as an independent variable in the model for online activism. 


\section{Analysis and Discussion}

Table 2 shows the results of the analysis. The first two columns show the results of the models for activism and cyber activism without controlling for parties. Columns 3 and 4 show the results of the models controlling for parties - i.e., system level variables. Let us first start by looking at the results for offline activism (Model 1). The first thing to note is that this is a poor model since it only accounts for $6 \%$ of the variance of the dependent variable (the R2 is 0,061 ). This would confirm Granik's (2005) thesis that we still lack a good model to account for party activism. Second thing to note is that, as expected, education has no effect on offline participation. But age and gender (in this case being a female) seem to have a slight effect in traditional or offline participation. In particular, increasing age by 1 year (for example moving from 47 to 48 years) reduces as an average offline participation by a factor of $1 / 80$ (Note that since the index of offline participation has been normalized to an index between 0 and 1, this factor has to be multiplied by $1 / 8$ to get the coefficient). Being a female also increases offline participation by a factor of $1 / 4$ (Again for the same reasons mentioned this has factor has to be multiplied by $1 / 8$ to get the coefficient). This effect however could be due to a problem in the data since for every woman in the sample there are more than 3 men. In particular, it could be due to a self-selection problem: since fewer women are active in party politics, those that are active could have special characteristics that in turn could explain them being more active as an average than men. Third thing to note is that none of the variables that are expected to affect online activism (such as frequency of use of the Internet, size of the municipality, and joining the party through the net) seem to have an effect in offline activism. Forth thing to note is that, as expected, what better accounts for offline activism is selective incentives and to a lesser extent ideological distance. Holding an office increases by a factor of almost $1(1 / 1.14$ or 0.87$)$ the normalized index of activism offline; or in other words, holding an office increases by almost one activity the additive index of offline participation. This result confirms that members that in addition to obtaining benefits from policy extract "private benefits" from their party's success tend to be more active than the average member. But proximity to the party seems to be an even more powerful predictor of activism offline, since it increases by a factor of 1 the normalized index of offline activism and by one activity the additive index of offline participation. In other words moving from being a web-visitor to being a sympathizer and from being a sympathizer to being a party member, as an average, increases in one activity the additive index of offline participation. What this result is saying is that since participation offline is costly we should only expect party members, who have a strong feeling of belonging and who obtain benefits from being formal members, to get involved in activism.

Table 2. Predictors of offline and online activism 


\begin{tabular}{|c|c|c|c|c|}
\hline & $\begin{array}{c}\text { (Model 1) } \\
\text { Index Activism } \\
(0-1)\end{array}$ & $\begin{array}{c}\text { (Model 2) } \\
\text { Index Cyber } \\
\text { activism (0-1) }\end{array}$ & $\begin{array}{c}\text { (Model 3) } \\
\text { Index } \\
\text { Activism (0-1) } \\
\end{array}$ & $\begin{array}{l}\text { (Model 4) } \\
\text { Index Cyber } \\
\text { activism (0-1) }\end{array}$ \\
\hline Age & $\begin{array}{l}-0.00159^{* *} \\
(0.000752)\end{array}$ & $\begin{array}{l}-0.00196 \\
(0.000548)\end{array}$ & $\begin{array}{l}-0.00153^{* x} \\
(0.000756)\end{array}$ & $\begin{array}{l}-0.00207^{*+1 *} \\
(0.000543)\end{array}$ \\
\hline Gender & $\begin{array}{c}0.0338^{*} \\
(0.0189)\end{array}$ & $\begin{array}{l}0.00388 \\
(0.0138)\end{array}$ & $\begin{array}{c}0.0323^{*} \\
(0.0190)\end{array}$ & $\begin{array}{l}0.00132 \\
(0.0136)\end{array}$ \\
\hline Education & $\begin{array}{c}-0.00733 \\
(0.00793)\end{array}$ & $\begin{array}{c}0.00777 \\
(0.00577)\end{array}$ & $\begin{array}{c}-0.00744 \\
(0.00792)\end{array}$ & $\begin{array}{c}0.00783 \\
(0.00569)\end{array}$ \\
\hline \multirow{2}{*}{$\begin{array}{l}\text { Ideological } \\
\text { distance }\end{array}$} & $0.00656^{*}$ & 0.00180 & 0.00384 & 0.00406 \\
\hline & $(0.00373)$ & $(0.00271)$ & $(0.00462)$ & $(0.00332)$ \\
\hline \multirow{2}{*}{$\begin{array}{l}\text { Identity } \\
\text { distance }\end{array}$} & -0.00345 & 0.000940 & 0.00140 & 0.000511 \\
\hline & $(0.00342)$ & $(0.00249)$ & $(0.00448)$ & $(0.00322)$ \\
\hline \multirow{2}{*}{$\begin{array}{l}\quad \text { Catalan } \\
\text { Nationalism } \\
\text { Index }\end{array}$} & 0.00148 & $0.00902^{* *}$ & 0.00492 & 0.00548 \\
\hline & $(0.00517)$ & $(0.00377)$ & $(0.00602)$ & $(0.00432)$ \\
\hline \multirow{2}{*}{$\begin{array}{c}\text { Members } \\
\text { holding office }\end{array}$} & $0.108^{\text {*tot }}$ & $0.156^{* * * *}$ & $0.106^{* \star * *}$ & $0.148^{\text {*t* }}$ \\
\hline & $(0.0173)$ & $(0.0126)$ & $(0.0174)$ & $(0.0125)$ \\
\hline \multirow{2}{*}{$\begin{array}{l}\text { Proximity } \\
\text { to the party }\end{array}$} & $0.119^{*+1+x}$ & $0.0882^{*+* t}$ & $0.127^{\text {t*t* }}$ & $0.0792^{\text {tw*t }}$ \\
\hline & $(0.0303)$ & $(0.0221)$ & $(0.0310)$ & $(0.0223)$ \\
\hline \multirow{2}{*}{$\begin{array}{r}\text { Years of } \\
\text { membership }\end{array}$} & $0.00221^{* *}$ & $0.00228^{\text {tatk }}$ & $0.00221^{* *}$ & $0.00254^{*+k t}$ \\
\hline & $(0.000950)$ & $(0.000692)$ & $(0.000956)$ & $(0.000686)$ \\
\hline Internet use & $\begin{array}{c}0.0135 \\
(0.00863)\end{array}$ & $\begin{array}{c}0.0347^{* * *} \\
(0.00629)\end{array}$ & $\begin{array}{c}0.0139 \\
(0.00865)\end{array}$ & $\begin{array}{l}0.0371^{* * *} \\
(0.00621)\end{array}$ \\
\hline \multirow{2}{*}{$\begin{array}{c}\text { Size of } \\
\text { municipality }\end{array}$} & 0.00364 & $0.0127^{*+k}$ & 0.00211 & $0.0101^{* *}$ \\
\hline & $(0.00551)$ & $(0.00401)$ & $(0.00555)$ & $(0.00398)$ \\
\hline \multirow{2}{*}{$\begin{array}{l}\text { Joining } \\
\text { through the } \\
\text { web }\end{array}$} & 0.0249 & $0.165^{*+1 * x}$ & 0.0219 & $0.157^{*+k}$ \\
\hline & $(0.0173)$ & $(0.0126)$ & $(0.0174)$ & $(0.0125)$ \\
\hline ICV & & & $\begin{array}{c}0.0442 \\
(0.0276)\end{array}$ & $\begin{array}{l}0.109^{\text {tat }} \\
(0.0198)\end{array}$ \\
\hline CDC & & & $\begin{array}{l}-0.0333 \\
(0.0363)\end{array}$ & $\begin{array}{l}0.0623^{* *} \\
(0.0260)\end{array}$ \\
\hline ERC & & & $\begin{array}{l}-0.0417 \\
(0.0317)\end{array}$ & $\begin{array}{c}0.0132 \\
(0.0227)\end{array}$ \\
\hline Cons & $\begin{array}{c}0.101 \\
(0.0931)\end{array}$ & $\begin{array}{l}-0.206^{*+* x} \\
(0.0678)\end{array}$ & $\begin{array}{c}0.0682 \\
(0.0971) \\
\end{array}$ & $\begin{array}{l}-0.190^{* * *} \\
(0.0697)\end{array}$ \\
\hline$N$ & 1171 & 1171 & 1171 & 1171 \\
\hline $\begin{array}{c}R 2 \\
\text { (Adjusted) }\end{array}$ & 0,060 & 0,26 & 0,062 & 0,28 \\
\hline
\end{tabular}


This model, however, not only finds support for Olson's theory about the role of selective incentives, it also finds some support -- although weaker -- for Aldrich (1983) argument concerning the importance of policy for party activists. It turns out that the more distant the activist perceives his party's main adversary to be in the ideological dimension the more prone he is to contribute to his party in valuable resources such as time, energy and money. In fact, a one point increase in the perceived distance between the activist's party and the main adversary in the ideological scale increases as an average the index of offline activism by a factor of $1 / 19$. This effect, however, is significant at the 0.1 level and disappears once we control for parties (see the second model for activism in Column 3). One interesting thing that this first model of activism tells us is that it is only ideology and not nationalism that matters for offline activism. In other words, it seems that there is only one relevant dimension mobilizing party members' offline and this is not identity but the traditional left-right divide.

Finally, if we now look at the second model of activism in Column 3, we find no support for the effect of systemic variables, such as party size and type of organization, in offline participation. Parties - or party characteristics -- do not make a difference in members' participation at least when it comes to offline participation. Being a member of the nationalist parties (CDC and ERC) has a negative effect on offline activism with respect to being a member of the Catalan socialist party while being a member of the red-green party (ICV) has a positive effect but since none of these effects are significant we cannot rule the null hypothesis -- that these differences are equal to zero.

Let us now focus on the results of the model(s) for online activism. First thing to note is that this is a much better model than the one for offline activism: it accounts for $26 \%$ to $28 \%$ of the variance of the dependent variable, a more than reasonable goodness of fit. Second, the set of socio-demographic variables have no effect in online participation except for age. Note that age both tends to have a slightly greater effect on (compare the size of the coefficient) and is a more reliable predictor (compare the significance level) of online participation than of offline participation. As age increases one year - for example, from 19 to 20 years -- online participation decreases by a factor of $1 / 27$. As expected, hence, the younger the member the greater the amount of activity online he or she is willing to undertake to help his or her party attain his goals. What is noticeable, in contrast to the previous model, is that all the variables that were expected to have an influence in the levels of participation online -frequency of use of the Internet, size of the municipality and joining the party online -do have an important and significant effect in online participation. For example, moving from using the Internet 4 or 5 days a week to using it 5 or 6 days increases online participation in almost one activity or by a factor close to one $(1 / 1,5$ or 0,66$)$; and 
joining the party through the net increases online participation in more than three activities of by a factor greater than 3 . In other words, those who join the party through the net happen to be very active online but not offline. Finally, we find that the size of the municipality has also an effect in online participation. Online activism tends to concentrate in big municipalities and not in small ones; or, in other words, those members living in big municipalities tend to be more active online than those living in small municipalities. Since none of these variables have effect on activism offline, we have probably found some support for the mobilization hypothesis. In fact, with a very high probability the profile of the member who is very active online is a frequent internet user, has approached the party through the Internet and lives in a big municipality. Again, as mentioned, none of these variables define the profile of those members who are active offline.

The model(s) for Cyber Activism also find support for Olson's argument concerning the influence of selective incentives in participation. Note that holding an office continues to be a very powerful predictor of online participation, and it is even stronger than for offline activism. In fact, holding an office increases the levels of online activism not by a factor of almost 1 as in offline activism but by a factor of 3 (since the additive index of online participation has more than twice the activities of the index of offline participation this factor must now be multiplied by $1 / 19$ to get the coefficient). In other words, members holding an office on average engage in 3 activities online more than members not holding an office and in 1 activity offline more than members not holding an office. Although not by much, proportionally the effect of holding an office is higher for online than for offline activism. Yet while holding an office tends to be more important for online participation than for offline participation, proximity to the party tends to be in proportion less important for online activism than for offline activism (compare the coefficients). In fact, moving one unit closer to the party (from being a sympathizer to being a member) tends to increase the number of activities offline in 1 , while it tends to increase the number of activities online in 1,7. Since the number of activities in the index of online participation is more than twice the number in the index of offline participation, in proportion (just as the coefficients reflect) proximity to the party has less effect in online participation than in offline participation. This has two possible explanations. First, since online participation is less costly than offline participation, the calculus of participating even without accruing the benefits of being a member may still be positive if there the benefits from policy are high enough. Second, since the Internet facilitates access to the party and "voluntary work" without having to become a member, it is plausible that some of those who approach the party through the Internet will remain active online without becoming formal members. This story finds some support in the previous finding that those who admit approaching the party through the Internet are the most active online. While some of these activists who approach the party online will follow through and formalize their membership some will not. 
This finding suggests two things. First that certain selective incentives associated with feelings of belonging to a group or to solidary and expressive benefits might be losing importance as the costs of participation - due to the Internet - decline. Second that, partly as a consequence of this, parties might be becoming more inclusive and barriers between members and non members might be wiping out. Finally, this finding provides additional support for the mobilization hypothesis.

But what is probably the most striking finding regarding the model for CyberActivism is that, in contrast to expectations and to Aldrich's argument, policy seems not to be important to explain online participation at least when measured as the distance. As column 2 of Table 2 shows, neither the distance in the ideological or territorial dimension has a positive and significant effect on the levels of online participation. This contrasts with the finding that ideology is an important factor explaining offline activism. Yet what seems to have an effect on levels of online participation is Catalan nationalism.

What this finding is seemingly telling us is that being more extreme in the dimension of Catalan nationalism or feeling more strongly in Catalan identity issues increases the level of activism online. In other words, what is mobilizing party members to participate online is not the traditional left-wing divide but the issue of Catalan national identity. The question is, why this result appears when we use self-location in the index of Catalan nationalism and not when we use the much more refined measure of the distance between the activist's party and its main adversary? A possible answer to this question is that in contrast to what happens in the left-right dimension where parties are really divided on ideological issues there is no such pronounced divide in the Catalan nationalist dimension. That is, all parties in the sample are probably perceived to be located within the centre to the extreme of the Catalan nationalist dimension; since distance or differences are not so pronounced in this dimension between the parties included in the sample (note that the right-wing Spanish nationalist party, the $\mathrm{PP}$, is not part of the study) the measure of the distance might not be a good one to capture the value of policy in this dimension. This is not completely but only slightly supported by the data. Whether the mean location of the conservative CDC as seen by the other parties is 7 , the mean location of the least Catalanist party, the PSC, as seen by the other parties is 5.6. In other words, while CDC is perceived to be clearly to the right of the scale by the other parties, the PSC is perceived by the other parties to be located slightly to the right but quite at the centre in the Catalan nationalist dimension.

While this is an interesting result, it must be interpreted cautiously. In fact, as Column 4 of table 2 shows, once we control for parties, the effect of being a strong Catalan nationalist disappears. But then it is easy to see that the nationalist parties, especially CDC, and IC-V (whose activists are also more extreme in the national dimension), have a positive and significant effect on the levels of activism online.

This suggests that there are at least two possible explanations for the result that Internet is especially mobilizing party activists with strong Catalan identity feelings. One possible explanation has to do with the nature of the "issue". The other possible 
explanation has to do with the organizational characteristics of the nationalist parties, and especially, of CDC. As it has been discussed, the Internet provides a new arena for minority and emerging political movements to become visible. Since nationalist movements are by definition minority movements, activists with strong Catalan nationalist feelings could be using the Internet as a platform to enhance the visibility of the Catalan nationalist movement and as an arena to reshape the existing power balance in favour of their cause. The second explanation, also plausible, has to do with the structure of the nationalist parties. Although both CDC and ERC have very different structures, in their own way they both have structures that give them an advantage in a virtual environment. ERC is a highly de-centralized party with a long tradition of member participation. Both this de-centralized structure and the youth of its membership explain an intense Internet activity within the party where rival fractions have organized and challenged the leadership using the Internet. As for the CDC more than a de-centralized party it has the structure of the catch-all party; with a ruling minority made up of professionals, a loose base of supporters and a volatile electorate. This loose structure, more similar to the American parties and to a movement than a party, as has been argued for the American parties, gives the party an incentive to use the Internet to mobilize its supporters and electorate. Finally, the data also supports the previous argument about the disadvantage that parties with a centralized and hierarchical structure, a big bureaucracy and a large territorial presence such as the PSC have in a virtual environment.

A final result deserves some comment. While this analysis provides ample evidence supporting the mobilization hypothesis, the analysis also shows that there is some overlapping between offline and online activism. In fact, as can be observed in the models of cyber activism, activism offline has always a positive and significant effect on the levels of activism online. That is, there is a set of activists that are both active offline and online. Or a set of activists who with the Internet have intensified their activity - these activists are sometimes labelled in the literature as "gladiators". These so-called "gladiators" represent almost $60 \%$ of the activists' offline and almost $50 \%$ of the activists online. While this result points to some reinforcement effect, we should not loose sight of the other $50 \%$ of cyber activists who before the Internet were either completely passive offline or minimally active, That is, while Internet is helping some traditional activists to intensify their activity it is also helping passive members or even loose supporters to become active for their parties. 


\section{Conclusions}

This study started up with the goal of testing the widely known reinforcement and mobilization hypothesis for party activism. These hypotheses have been tested in the area of political participation and in the area of online electoral competition, but had yet to be tested for party activism.

Some of the results of this study point to some reinforcement effects but to a net mobilization effect of the Internet in party activism. While this study shows that the Internet is being used to some extent by traditional party activists to intensify their activity (hence, the reinforcement effect), the overall net effect of the Internet in party activism seems to be one of mobilization. This paper has shown that patterns of activism online do not conform to patterns of activism offline because the determinants of activism online are not the same as the determinants of activism offline. This paper has shown, in line with other studies of political participation, that the individual resources and skills needed to participate online are not the same as those needed to participating offline. In fact, while the frequency of use of the Internet and accessing the party through the net are shown to be powerful determinants of activism online they are completely insignificant for activism offline. More importantly, this paper has shown that the organizational and political resources needed to mobilize party members' offline are not the same as those needed to mobilize party member online. This would explain why the size of the municipality is relevant for online participation while it is completely irrelevant for offline mobilization. This could also explain one of the most interesting findings of this paper: that while traditional activism continues to mobilize party members in the traditional left-right wing divide, the Internet seems to be mobilizing party members in the issue of Catalan national identity. This finding could be the result of either the nationalist parties having a less hierarchical structure than the traditional mass-party structure of left-wing parties or of followers with strong preferences in the Catalan national identity dimension having an incentive to use the Internet to reshape political conflict in favour of the cause of an independent Catalonia.

\section{Bibliographic references}

Aldrich, John. 1983a. "A Downsian Spatial Model with Party Activims". The American Political Science Review 77(4): 974-990

Aldrich, John. 1983b. "A spatial model with party activists: implications for electoral dynamics". Publuc Choice 41: 63-100.

Anduiza, Eva.; Gallego, Aina.; Jorba, Laia. 2009. "The Political knowledge Gap in the New Media Environtment: Evidence from Spain". Paper presented at the International Seminar "Citizen Politics: Are the New Media reshaping Political Engagement?" Barcelona, May 28th-30th. 
Best, Samuel; Krueger, Brian. 2005. "Analyzing the Representativeness of Internet Political Participation". Political Behavior 27(2): 183-216.

Bimber, Bruce. 2001. "Information and Political Engagement in America: The Search for Effects of Information Technology at the Individual Level". Political Research Querterly 54 (1): 53-67.

Bonchek, Marc. 1995. "Grassroots in Cyberspace: Recruiting Members on the Internet or Computer Networks Facilitate Collective Action?," paper presented at the 53rd Anual Meeting of the Midwest Political Science Congress.

Borge, Colombo and Welp. 2009. "Online and Offline participation at the local level". Information, Communication and Society: 1-30.

Borge, R.; Cardenal, A.S (2011) "Surfing the Net: a pathway to participation for the politically uninterested?" Internet and Policy 3:1.

Boulianne, Shelley. 2009. "Does Internet Use Affect Engagement? A Meta-Analysis of Research". Political Communication 26: 193-211.

Cantijoch, Marta. 2009. "Reinforcement and mobilization: the influence of the Internet on different types of political participation". Paper prepared fro delivary at the seminar "Citizen Politics: Aret he New Media Reshaping Political Engagement?" Barcelona (May 28th-30th).

Clark, P.B and Wilson, J.Q. 1961. "Incentive Systems: A Theory of Organizations", Administrative Science Quarterly 6: 129-66.

Duverger, Maurice. 1957. Los partidos políticos. México: Fondo de Cultura Económica.

Farmer, Rick and Rich Fender. 2005. "E-Parties: Democratic and Republican State Parties in 2000". Party Politics 11(1): 47-58.

Farnsworth, Stephen and Diana Owen. 2004. "Internet use and the 2000 presidential election". Electoral Studies 23: 415-429.

Farrell, David, Kolodny, Robin, and Stephen Medvic. 2001. "Parties and Campaign Professionals in a Digital Age". Politics 6(4):11-30.

Foot, Kirsten and Steven Schneider. 2002. "Online Structure for Political Action: Exploring Presidential Campaign Web Sites From the 2000 American Election". The public 9(2): 43-60.

Gibson, Rachel, and Stephen Ward. 1998. "UK Political Parties and the Internet: Politics as Usual in the New Media?" Harvard International Journal of Press / Politics 3 (3):14-38.

Gibson, Rachel; Lusoli, Wainer; Ward, Stephen. 2005. "Online Participation in the UK: Testing a 'Contextualized' Model of Internet Effects". British Journal of Politics and International Relations 7: 561-583.

Granik. Sue. 2005. "A Reconceptualization of the Antecedents of Part Activism: A Multidisciplinary Approach". Political Studies 53:598-620.

Harmel, Robert, and Kenneth Janda. 1994. "An integrated theory of party goals and part change," Journal of Theoretical Politics, 6(3): 259-287.

Heidar, Knut, and Jo Saglie. 2003a. Predestined Parties? Organizational Change in Norwegian Political Parties. Party Politics 9 (2):219-239.

Heidar, Knut, and Jo Saglie. 2003b. "A decline of linkage? Intra-party participation in Norway, 1991-2000". European Journal of Political Research 42:761-786.

Jensen, Michael. 2009. "Political Participation, Alienation, and the Internet in the United States and Spain". Papepr presented at the International Seminar "Citizen Politics: Are the New Media reshaping Political Engagement?" Barcelona, May 28th-30th. 
Jones, Philip, and John Hudson. 1998. "The Role of Political Parties: An Analysis Based on Transaction Costs". Public Choice 94:175-189.

Katz, Richard S. 2001. The Problem of Candidate Selection and Models of Party Democracy. Party Politics 7 (3):277-296.

Katz, Richard; and Peter Mair. 1995. "Changing Models of Party Organization and Party Democracy: The Emergence of the Cartel Party," Party Politics 1(1): 528.

Krueger, Brian. 2002. "Assesing the Potential of Internet Political Participation in the United Sates: A Resource Approach". American Politics Research 30 (5): 476498.

Krueger, Brian. 2006. "A Comparison of Conventional and Internet Political Mobilization". American Politics Research 34 (6): 759-776.

Löfgren, Karl. 2000. "Danish Political Parties and New Technology: Interactive Parties or New Shop Windows," in J. Hoff, J. Hooroks and P. Tops (eds), Democratic Governance and New Technology, London: Routledge.

Löfgren, Karl. 2003. "Intraparty use of new ITCs - Bringing Party Membership Back In?, paper presented to the ECPR Joint Sessions, Edinburgh, Scotland.

Lupia, Arthur \& Sin, Gisela, 2003. "Which Public Goods Are Endangered?: How Evolving Communication Technologies Affect The Logic of Collective Action," Public Choice, Springer, vol. 117(3-4), pages 315-31, December.

Lusoli, Wainer and Stephen Ward. 2004. "Digital Rank-and-file: Party Activists' Perceptions and Use of the Internet". British Journal of Politics and International Relations 6: 453-470.

Margetts, Hellen. 2001. The Cyber Party. Paper read at "The Causes and Consequences of Organizational Innovation in European Political Parties" ECPR Joint Sessions of Workshops, at Grenoble, 6-11 April.

Margolis, Michael, and David Resnick. 2000. Politics as Usual: The Cyberspace 'Revolution'. Thousand Oaks: Sage.

Newell, James. 2001. "Italian Political Parties on the Web," Harvard International Journal of Press / Politics 6 (4):60-87.

Norris, Pippa. 1999. Democratic Phoenix: Reinventing Political Activism. New York: Camdridge University Press.

Norris, Pippa. A virtious circle. New Yok: Cambridhe University Press.

Norris, Pippa. 2003. "Preaching to the Converted? Pluralism, Participation and Party Websites". Party Politics. Vol. 9 (1): 21-45.

Olson, Mancur. 1965. The Logic of Collective Action. Cambridge: Harvard University Press.

Panebianco, Angelo. 1988. Political Parties: Organization and Power. Cambridge: Cambridge University Press.

Pedersen, Karina, and Jo Saglie. 2005. "New Technology in Ageing Parties," Party Politics 11(3):359-377.

Seyd, Patrick; Whiteley, Paul. 2004. "British Party Members: An Overview". Party Politics 10: 355-366.

Strandberg, Kim. 2008. "Online Electoral Competition in Different Settings: A Comparative Meta-Analysis of the Research on Party Websites and Online Electoral Competition". Party Politics 14(2): 223-244.

Tan, Alexander. 1998. "The Impacts of Party Membership Size: A Cross-National Analysis". The Journal of Politics 60(1): 188-198. 
Tolbert, Caroline J.;McNeal, Ramona. 2003. "Unraveling the Effects of the Internet on Political Participation". Political Research Quarterly 56(2): 175-185.

Ward, Stephen; Lusoli, Wainer; Gibson, Rachel. 2002. "Virtually participating: A survey of online party members". Information Polity 7: 199-215.

Ward, Stephen; Gibson, Rachel; Lusoli, Wainer. 2003. "Online Participation and Mobilization in Britain: Hype, Hope and Reality". Parliamentary Affairs 56: 652668.

Ware, Alan. "Activist-Leader Relations and the Structure of Political Parties: 'Exchange' Models and Vote-Seekings Behaviour in Parties". British Journal of Political Science 22(1): 71-92.

Weldon, Steven. 2006. "Downsize my Polity? The Impact of Size on Party Membership and Member Activism". Party Politics 12(4):467-481.

Whiteley, Paul; Seyd, Patrick. 1998. "The Dynamics of Party Activism in Britain: A Spiral of Demobilization". British Journal of Political Science. 28: 113-137. 


\author{
Ana Sofia Cardenal Izquierdo \\ acardenal@uoc.edu \\ Programa de Ciencia Política \\ Universitat Oberta de Catalunya
}

Ana Sofía Cardenal es profesora de Ciencia Política en la Universitat Oberta de Catalunya. Tiene numerosas publicaciones en política comparada, concretamente, en temas relativos a

transiciones hacia la democracia e instituciones políticas en América Latina. Ha sido investigadora visitante en diversas universidades extranjeras, entre ellas, Stanford y NYU.

Imparte clases de política comparada en la UOC y en la UPF. Recientemente, su investigación se ha centrado en los usos de Internet por parte de los partidos políticos y en la influencia de Internet en la participación política. Dentro del IN3, forma parte del grupo de investigación GADE (Gobernanza, Administración y Democracia Electrónica), reconocido por el IN3 y también como grupo emergente por la Generalitat de Catalunya. En 2009/2010 fue investigadora residente en el IN3 con un proyecto sobre partidos políticos e Internet. Como resultados de esta etapa destacan las publicaciones: "Why Mobilize Support Online?: The

Paradox of Party Behavior Online" (forthcomming en Party Politics) y (con Rosa Borge) "Surfing the Net: A Pathway to Participation for the Politically Uninterested?" (forthcomming en Internet and Policy)

\author{
Ana Sofia Cardenal Izquierdo \\ acardenal@uoc.edu \\ Programa de Ciencia Política \\ Universitat Oberta de Catalunya
}

Ana Sofía Cardenal es profesora de Ciencia Política en la Universitat Oberta de Catalunya. Tiene numerosas publicaciones en política comparada, concretamente, en temas relativos a transiciones hacia la democracia e instituciones políticas en América Latina. Ha sido investigadora visitante en diversas universidades extranjeras, entre ellas, Stanford y NYU.

Imparte clases de política comparada en la UOC y en la UPF. Recientemente, su investigación se ha centrado en los usos de Internet por parte de los partidos políticos y en la influencia de Internet en la participación política. Dentro del IN3, forma parte del grupo de investigación GADE (Gobernanza, Administración y Democracia Electrónica), reconocido por el IN3 y también como grupo emergente por la Generalitat de Catalunya. En 2009/2010 fue investigadora residente en el IN3 con un proyecto sobre partidos políticos e Internet. Como resultados de esta etapa destacan las publicaciones: "Why Mobilize Support Online?: The

Paradox of Party Behavior Online" (forthcomming en Party Politics) y (con Rosa Borge) "Surfing the Net: A Pathway to Participation for the Politically Uninterested?" (forthcomming en Internet and Policy). 


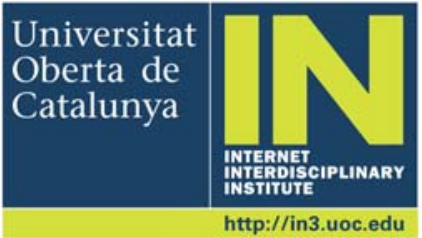

